\title{
Author Correction: The structure of a red-shifted photosystem I reveals a red site in the core antenna
}

\author{
Hila Toporik (D), Anton Khmelnitskiy, Zachary Dobson (D), Reece Riddle (D), Dewight Williams, Su Lin, \\ Ryszard Jankowiak \& Yuval Mazor (B)
}

Correction to: Nature Communications https://doi.org/10.1038/s41467-020-18884-w, published online 19 October 2020.

The original version of this Article omitted a reference to previous work in "Li, M., Semchonok, D. A., Boekema, E. J. \& Bruce, B. D. Characterization and evolution of tetrameric photosystem I from the thermophilic cyanobacterium Chroococcidiopsis sp TS-821. Plant Cell 26, 1230-1245 (2014)". This has been added as reference 51 which has been added at the end of the fourth sentence of the third paragraph of the Discussion: "The short loop present ... Chroococcidiopsis sp. TS-821 (PDBID: 6QWJ) 51 ".

The work in reference 50 was cited in the wrong location. It is now cited at the end of the previous sentence as reference 49: "The red loop we added to the Synechocystis WT PSI based on T. elongatus structure can also be found in Thermosynechococcus vulcanus ${ }^{46}$, Fischerella thermalis ${ }^{47}$ and Nostoc sp. PCC $7120^{48,49 "}$.

This has been corrected in the PDF and HTML versions of the Article.

Published online: 20 November 2020

\begin{abstract}
(c) Open Access This article is licensed under a Creative Commons Attribution 4.0 International License, which permits use, sharing, adaptation, distribution and reproduction in any medium or format, as long as you give appropriate credit to the original author(s) and the source, provide a link to the Creative Commons license, and indicate if changes were made. The images or other third party material in this article are included in the article's Creative Commons license, unless indicated otherwise in a credit line to the material. If material is not included in the article's Creative Commons license and your intended use is not permitted by statutory regulation or exceeds the permitted use, you will need to obtain permission directly from the copyright holder. To view a copy of this license, visit http://creativecommons.org/licenses/by/4.0/.
\end{abstract}

(C) The Author(s) 2020 